\title{
Pollination Characteristics of Pecan Trees and Orchards
}

Bruce W. Wood

AdDitional INDEX WORDS. Flowering, production, orchard management, temperature, age, Carya illinoenss

Summary. There is increasing evidence of substantial pollination related crop losses by pecan [Carya illinoensis (Wangenh.) K. Koch] orchards. These most likely occur in block-type orchards consisting of only one or two cultivars, but can also occur at locations with a great number of different genotypes nearby. M ain crop cultivars should generally be within about two rows of pollinizers to ensure cross-pollination. Thus, block widths exceeding about four rows between pollinizers are especially likely to exhibit serious pollination problems. Scattered trees of off-type genotypes are potentially of major importance as backup orchard pollinizers. Tree age/ size and spring temperatures influence the characteristics of flower maturity windows and are probably primary factors contributing to pollination-related fruit-set losses in many block-type orchards. Flower maturity tends to be earlier in older/ larger trees while warmer springs accelerate catkin development relative to that of pistillate flowers. Because of substantial variability in relative differences associated with initiation and duration of flower maturity windows within either protandrous or protogynous flowering types (i.e., T ype I or II), selection of complementary pollinizers should be based on the relatively high resolution 30 class flowering classification system rather than the traditional low resolution 2-class system. 0 ther factors sometime causing pollination related crop losses are either abnormally wet weather or strong dry winds during the pollination period or abnormally warm or cool springs. Pollination problems can be visually detected by noting premature non insect related post pollination fruit drop or diminishing fruit set with increasing distance from pollinator trees or off-type genotypes within the orchard.

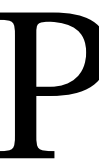

ecan is a silvicultural (Fowells, 1965) and horticultural crop (Flack, 1970; Wood et al., 1990). I ts native range appears to extend discontinuously from northern I owa ( $42^{\circ} 20^{\prime} \mathrm{N}$. L at.) in the $U$ nited States to the vicinity of $\mathrm{O}$ axaca ( $16^{\circ} 30^{\prime} \mathrm{N}$. L at.) in southern M exico (Thompson and Grauke, 1991) where it grows along the floodplain of the M ississippi, O hio, Arkansas, I llinois, M issouri, $\mathrm{N}$ ueces, Colorado, Brazos, Trinity and Red Rivers and their tributaries and in isolated pockets along the small rivers of central and southern M exico (Fowells, 1965). As a popular horticultural crop, pecan is increasingly planted outside of its native range in the U.S. and is also planted worldwide. Even in the U.S., orchards can be at least 1,000 miles $(1,600 \mathrm{~km})$ from the nearest native stands.

$M$ any pecan plantings, both within and outside of the native range, are established in large blocks consisting of only one or two cultivars. This is with the assumption that sufficient cross-pollination for good fruit set is not problematic.

U. S. D epartment of Agriculture-Agricultural Research Service, Southeastern Fruit and Tree Nut Research Laboratory, Byron, GA 31008.

The cost of publishing this paper was defrayed in part by the payment of page charges. U nder postal regulations, this paper therefore must be hereby marked advertisement solely to indicate this fact. 
This is based on the copious production of pollen by trees (Woodroof, 1924 ), long distance dispersal by wind, likely proximity of trees within the neighborhood, and relatively high viability of pollen grains (Woodroof, 1927). For example, a single 13-yearold ' $M$ antura' pecan tree was reported to produce pollen sufficient for the production of 29 billion nuts (Woodroof and Woodroof, 1924). Thus, pecan pollination has received little attention since the early 1930s until recently.

Pecan orchards in the U.S. were first established in the late 1800s and early 1900 s. Theimportance of careful selection of cultivars to compensate for dichogamy and climaticallyinduced variations in pollen maturity and dispersal patterns has been repeatedly stressed (Adriance, 1931; $M$ adden and Brown, 1975; M arquard, 1988; Romberg, 1931; Smith and Romberg, 1932, 1940; Stuckey, 1916; Wood 1997; Wood and M arquard 1992; Wood et al., 1997). M any of these original orchards are still cultivated. It was recognized as early as 1916 by Stuckey that orchardsshould be established using complementary cultivars in close proximity in order to ensure proper fruit set; however, most early orchards were planted in large blocks of only one or two cultivars. The frequency of off-type trees, due to graft failures was usually substantial, thus providing serendipitous and random sources of pollen within orchards. Recent investigations into poor fruit set and filling problems in orchards appearing to receiving near optimal culture found that cross-pollination remains a problem in many orchards (M arquard, 1992; Wood and M arquard, 1992; Wood, 1997). Pecan pollination characteristics and factors affecting pollination are therefore reviewed to provide insight into how to minimize pollination related crop losses.

\section{Flowering types}

Pecan is a wind pollinated monoecious crop exhibiting hetero-dichogamy (Adriance, 1930; Graukeand Thompson, 1996). Flowering is dichogamous within an individual tree or cultivar. Thus, there is a difference in the location and timing of functioning femal eand male organs. Thischaracteristic encourages out-crossing and ensuring genetic diversityin wild popu- lations. Individual trees and cultivars are therefore almost always either protogynous (female organ matures first) or protandrous (male organ matures first). Protogony is dominate, under control of a single major gene, but also with secondarymodifier genes likely being involved (Thompson and Romberg, 1985). Synchrony of pollen release and pistillate flower receptivity varies from none to complete and is influenced by genotype and environmental conditions (Wood et al., 1997; Worley et al., 1992). Dichogamy is generally incomplete in most pecan cultivars. Pollination dynamics can thereforecausefruit set problems. Crop losses can be due to poor pollination, excessive self-pollination, or xenia (Romberg and Smith, 1946).

\section{Staminate inflorescence}

The staminate inflorescence (i.e., the group of catkins) is produced during the spring that pollen sheds. Two to four groups can be found at each bud site on current season shoots. These groups consist of three catkins joined to a common stalk. Protogynous cultivars produce long, thin catkins possessing long, thin bracts whereas protandrouscultivarsproducerelatively short, wider catkins and bracts (Woodroof and Woodroof, 1929). The dichogamy type of most cultivars is therefore relatively easily identified from a distance by the general appearance of catkins. Protogynous and protandrouscultivarsalso differ in that the development of catkinsissuch that protogynous cultivars initiate anthers on catkins during the spring that pollen is shed whereas protandrous cultivars do so the summer prior to pollen shed (Wetzstein and Sparks, 1984). These catkins are composed of about 100 to 400 individual staminate flowers with each anther possessing four pollen sacs containing about 365 pollen grains each (Woodroof, 1930).

\section{Pollen characteristics}

Pecan pollen was studied by Wetzstein and Sparks (1985). They found pollen to be triporate, paraisopolar, and suboblate, with a tectateand microechinatesurface. The pores are located toward one pole and are thus within one hemisphere (i.e., paraisopolar). Grains are circular in polar view and suboblate in equatorial view. Grains exhibit three apertures (triporate) which are circular and non bordered with the exine thickening around these pores. The surface of the pollen grain is tectate and microechinate or spiniferous with surface sculptures being scattered and about $0.2 \mu \mathrm{m}$ high. Structurally malformed grains appear to be uncommon, but are enfolded at anthesis. When pollen is placed on a moist stigmatic surface or on germination medium, it hydrates quickly, becomes spherical, and can produce a pollen tube within about $1 \mathrm{~h}$. O bservations by Wetzstein and Sparks (1985) suggests that pollen under field conditions is short-lived, because germination percentage decreasing rapidly after storage $5 \mathrm{~d}$ at room temperature. Similarly, Woodroof (1930) found that pollen failed to germinate after 72 to $96 \mathrm{~h}$ of storage at room temperature. There seems to be insufficient morphological differencesamong cultivars to allow for identification to the cultivar level based on morphology, although identification is possible by molecular approaches (W etzstein and Sparks, 1985).

\section{Dispersal strategy}

Pollen dispersal within trees varies with tree position. C atkins located in the lower interior of the tree usually shedding first whereas those at the top of the tree shed last. Within a current season shoot, pollen release proceeds from the base of the shoot toward the tip. Because pollen maturity is closely linked with bud break, years experiencing weather conditions leading to uneven bud break will also exhibit uneven pollen shed. Rate of flower development isinfluenced bytemperature, thus abnormally warm or cool springsnot only alter the date of pollen shed, but also disrupts the timing of flower maturity between male and female flowers because their relative maturity rates do not respond equally to changesin temperature(Wood, 1997). Thus, unusual spring temperaturescan alter pollen shed and stigma maturity windows and lead to insufficient pollination.

Pollen is shed when the mature pollen sacs longitudinally split upon drying (Woodroof, 1930). Released pollen grainsareflattened or concaved, thus providing greater lift and ability to be dispersed by wind before settling to the ground. A gentle tap or shaking of limbs will release a cloud of pollen when conditions are met for dehis- 
cence. Timing of this dehiscence is strongly influenced by both temperature and relative humidity of the surrounding air. Dehiscence appears to occur when relative humidity is below about 85\%(Woodro of and Woodroof, 1929), thus dehiscence in the humid southeastern U.S. usually does not occur before mid morning whereas shed can begin earlier in the drier southwestern U.S. D ry air at relatively high temperatures, especially with winds to desiccate the anther will hasten pollen dispersal and also shorten duration of release by the tree. These conditions also shorten the pistil's receptivity period. Conversely, moist and cool conditions can lead to a protracted and delayed dispersal of pollen and can extend the period of pistil receptivity. Especially wet conditions can result in an immense release of pollen as soon as lower humidity (i.e., less than about 85\%) allow the anthers to split. The period of pollen dispersal can extend from about 3 to $10+d$, depending upon environmental factors. The pattern of release exhibits a normal distribution, but can beskewed due to environmental reasons.

\section{Pistillate inflorescence}

To achieve proper fruit set it is important that pistillate flowers receive the proper amount of pollen at the proper time and that environmental conditions are suitable for pollen germination and subsequent fertilization. These pistillate flower targets are produced in a cluster, on a spike, at the tip of current season shoots. These flowersaredifferentiated in early spring after receiving a requisite exposure to low temperatures(Amling and A mling, 1983) and typically result in 1 to 6 flowers per cluster. Abnormal weather or insect damage can occasionally produce clusters consisting of about 20 to 100 flowers, of which most typically set fruit.

The maturation of pistillate flowersproceeds acropetally, from the base to the tip of the cluster. The bilobed stigma of the developing pistil occurs in a variety of colors, sizes, and shapes, depending upon cultivar. For example, color can range from dark green to light green to yellow to pink to red to purple. Stigma color appears to be unrelated to time of receptivity. The surface of the stigma develops a wetlike appearance at or about the time that they becomereceptive (W etzstein and Sparks, 1983). This appearance is thought to be closely associated with the state of receptivity (Woodro of and Woodroof, 1926; Adriance, 1931). The stigmatic surface has rounded, projecting papillae that give it a rough appearance. These papillae excrete an exudate that secures pollen grains to the stigmatic surface upon contact. Thisnon copioussurface exudateforms a pattern of thicker and thinner patches and appears to correspond to the $\mathrm{H}$ eslop-H arrison and Shivannna's Group IIBi stigma type (H eslop$\mathrm{H}$ arrison and Shivanna, 1977; Wetzstein and Sparks, 1986). The adherence of pollen dusted onto the stigmatic surface is generally regarded as reflecting the window of receptivity and istherefore used to describematurity patternsfor cultivars in attemptsto ensure selection of complementary cultivars in plantings. I ndividual flowers and the flowers within a single cluster are usually receptive within a about $2 \mathrm{~d}$ period (Smith and Romberg, 1941), however a span of about 4 to $10+d$ occur for all flowers within a tree to become receptive (Wood et al., 1997). The maturity pattern for pistillate flowers is that of a normal curve, but can be substantially skewed dueto temperature, humidity and likely other environmental factors.

\section{Fertilization process}

Pollen grains are polarly flattened at anthesis, but become rounded and fully hydrated within about $1 \mathrm{~h}$ after exposure to the exudate found on the surface of receptivestigmas (Wetzstein and Sparks, 1989). After pollination, pollen grains appear to germinate within about $3 \mathrm{~h}$ (Wetzstein and Sparks, 1989) with pollen tubesgrowing along the stigmatic cell surfaces and downward toward papilla cell junctions where they enter the stigmatic surface between adjacent stigmatic cells. They then grow rapidly toward the ovule. This growth has been estimated to have been about $150 \mu \mathrm{m} \cdot \mathrm{h}^{-1}$ from 3 to $8 \mathrm{~h}$ after pollination ( $M$ arquard, 1992). Thestigmatic surface beginsto degenerate shortly after being pollinized, resulting in a general darkening of the stigmatic surface beginning within about $24 \mathrm{~h}$ of pollination (Wetzstein and Sparks, 1989). Stigmatic cells are flattened by about $48 \mathrm{~h}$ after pollination. M cKay (1947) observed that polar fusion of the nucleus with one of the male gametes occurs about $4 \mathrm{~h}$ after pollination, resulting in the formation of the endosperm nucleus. Thisnuclear endosperm is recognized in developing fruit as the liquid endosperm (Woodroof, 1928; Yates and Sparks, 1993). The second gamete fuses with the egg about 4 to $7 \mathrm{~d}$ post pollination.

If stigmatic surfaces receive excessive pollen, such as in controlled crosses, proper fertilization does not occur, causing fruit to abort within a few weeksafter being pollinized (Romberg and Smith, 1950). There is circumstantial evidencein english walnut (Juglans regia L.) that the temperature at which pollen develops can influence its germination characteristics when exposed to higher or lower temperatures (Polito et al., 1991). If such a temperature adaptation response occurs in pecan then a substantial rise or fall in temperatures during the pollination period might result in poor germination of pollen on the stigmatic surface and subsequently reduced fruit set. It is also observed in walnut that orchard trees of certain cultivars often experienceyield lossesdueto exposure to excessive amounts of pollen (M cG rahahan et al., 1994). T his trait appears to occur for only a few walnut varieties (G.S. Sibbett, personal communication) and isnot presentlyknown to occur in pecan cultivars in orchards.

\section{Pollination related fruit drop}

D eveloping pecan fruit can abort during the time prior to pollination to many months afterwards. Pollination appears to play a rolein fruit drop, with pollination problems potentially being recognized by the degree and pattern of fruit drop. Four categories of fruit drop have been described that covers the entire fruit development period (Sparks and M adden, 1985). It waslong recognized that pistillateflowers abscising at the time of full bloom are weak and underdeveloped (Woodroof, 1928). The occurrence of such flowers and the associated drop is inversely related to shoot vigor (I sbell, 1928). The second drop, occurs just after pollination, begins about $14 \mathrm{~d}$ after pollination and continuing up to about $45 \mathrm{~d}$ post pollination (Smith and R omberg, 1941). This drop coincides with non pollinated controls, therefore being thought to be due to lack of fertilization (Sparks and M adden, 1985). Thisdrop also occurswhen treesareself-pollinated. Thusfruit drop 
from about 14 to $45 \mathrm{~d}$ after pollination is likely due to problems with pollen availability or to self-pollination. A third drop occurs about 54 to $90 \mathrm{~d}$ post pollination and corresponds with the first and subsequent divisions of the zygote (M cKay, 1947). This drop is thought to be due to failure of the zygote to divide, resulting in abortion of the embryo shortly thereafter. This drop appears to be enhanced by selfpollination (Sparks and $M$ adden, 1985). The fourth drop tends to be more subtle than the previous three drops, is associated with apparent embryo abortion wheretheembryo shrivels with no discoloration of the seed coat or accompanying tissues. This drop may also be associated with selfpollination or incompatible parentage.

\section{Incompatibilities}

It appears that viable pollen from any pecan source can successfully fertilize pistillate flowers. $\mathrm{H}$ owever, circumstantial evidence indicates the existence of incompatibilities to such a degree that certain cultivars appear to tolerate self-pollination much better than do others and that certain pollen parents produce greater fruit sets than others (personal observations). Pecan also exhibits a xenia effect in that pollen source affects kernel filling and perhapsother nut characteristics(Romberg and Smith, 1946).

\section{Pollination problems}

A rapid increase in establishment of pecan orchards in the southwestern U.S., far outside of the native range, led to a renewal of interest in pollination related concernsin commercial orchards. Investigation of these orchards by $M$ arquard (1988) revealed that pollination problems were more common and severe than commonly supposed. M ost southwestern orchards consist of 'W itchita' and 'Western Schley', both generally regarded as mutually complementary. It was discovered in these orchards that yield losses occur when pollinizers are two or more rows away from the main crop. M uch of this loss wasasso ciated with reduced kernel quality due to self-pollination. The further treeswerefrom thepollinizer, thegreater was the percentage of self-pollination.

Relative abundance of diverse cultivarsand feral germplasm proximate to most orchards in the central and southeastern U.S. has contributed to the commonly accepted belief that pollina- tion is not a problem in this region where most of the U .S. pecan production originates (Wood et al., 1990). This was partially based on observations of the great abundance (Woodroof, 1924, 1930) and mobility (Woodroof and Woodroof, 1927) of pollen produced by trees and its potential availability to regional orchards. N evertheless, the detection of extensive self-pollination in many southeastern blocktype orchards by Wood and M arquard (1992) using isozyme techniques suggests that pollinizer-related crop losses are far more likely than commonly supposed and is especially likely to occur in block-type orchards. Thus, for the first time since the first half of the 20th century(Stuckey, 1916; Adriance, 1931; Romberg, 1931; Smith and Romberg, 1946) these findings not only raise the question of serious pollination problems in areas where pecan in commonly cultivated, but also quantified severity of problem in orchards typical of many within the region.

An intensification of effortsto study pollination in block-type planting in Georgiademonstrated pollination problems in a 'D esirable'/ 'Stuart' (i.e., 20 rows 'D esirable' and 4 rows of 'Stuart' in a repeating pattern) orchard (Wood, 1997). 'D esirable' was grown as the main crop and 'Stuart' as the pollinizer. This combination has historically been regarded asmutually complementary in regards to flower maturity. The investigation revealed serious pollination related fruit set problems in certain years and with a sigmoidal decline in fruit set in 'D esirable' trees as distance from the 'Stuart' pollinator increased. It was also evident in such orchards that off-genotypes (i.e., other cultivars or seedling trees) in the central region of these blocks were usually surrounded by ' $D$ esirable' trees with heavy fruit set, but with declining fruit set with increasing distance from the off-type genotypes. Thus, off-genotypes are potentially of substantial importance as backup pollinizers and therefore ensure against crop lossesdueto poor pollination. This study showed that maximum fruit set occurs on rowsimmediately adjacent to the pollinizer and that crop trees should not be more than two trees from the pollinizer if pollen related crop loss is to be avoided. Thus, blocks should probably not consist of more than four rows of a single cultivar before joining a pollinizer row. It appears that proper pollination is more closely linked to the amount of canopy between thepollinizer and the target tree than to the distance the target tree is separated from the pollinizer. Thisstudysuggeststhat greatest cross-pollination is achieved when trees are adjacent to pollinizers and that the amount of canopy pollen must penetrate to reach target trees is more important than is the distance that pollen travels.

Experiences related by orchard managers in areas outside the native range of pecan indicate that highest kernel quality occurs when trees are adjacent to pollinizers and that quality declines with increasing row distance from the pollinizer. This likely reflects a self-pollination problem, although reduced fruit-set may also be involved. Similarly, highest fruit quality and yields are reported on trees in plantings consisting ofalternating rows of two complementary varieties (such as 'Wichita' and 'Western Schley'). T reesin many southeastern U.S. orchards typically exhibit greatest fruit-set when either downwind from wild or feral trees or on the windward margins of orchards.

Pollination related problems can al so occur in orchards located in regions where wild pecan trees are abundant. The potential for a population of wild trees to produce a great abundance of pollen dispersed over a long period of time is suggestive that cross-pollination is unlikely to beaproblem in block-type planting near wild trees. H owever, this does not always appear to be the case. For example, a large 'Wichita' orchard along the Colorado River in Texas exhibited near total crop failure - in a season following an abnormally dry autumn, winter, and spring - except for trees along the edge of the orchard facing the river where canopies were exposed to pollen from wild trees. Fruitset in this orchard declined from the perimeter to the interior with fruit-set decreasing sharply after 4 rows into the orchard (personal observation). Thus, crop losses due to poor cross-pollination can also occur at locations with abundant wild trees.

\section{Influence of spraying during pollination periods}

The influence of foliar sprays of trace elements or pesticides on fertilization of pistillate flowers, when applied at or about the time of stigma receptivity, have been of concern as factors potentially contributing to pollination related crop losses. Research 
by H eand W etzstein (1994) indicated that certain fungicides applied during microspore development may potentially influence fertilization. Subse- quent field studies by R eilly and Wood (1996) evaluated the impact of standard foliar zinc and fungicide sprays (i.e., propiconazole, fentin hydroxide, or fenbuconazole) found no detectable influence on fertilization or fruitset of either 'C heyenne' or 'D esirable' trees in orchards. H owever, the effect

T able 1. Flowering classification of pecan cultivars at different ages. Classes reflect pollination and receptivity periods for ensuring cross-pollination. Type I = protandrous (pollen releasing first), T ype II = protogynous (pistillate flowers receptive first); $V E=$ very early, $E=$ early, $M=$ mid, $L=$ late, $V L=$ very late maturity of the respective flower type. ${ }^{2}$

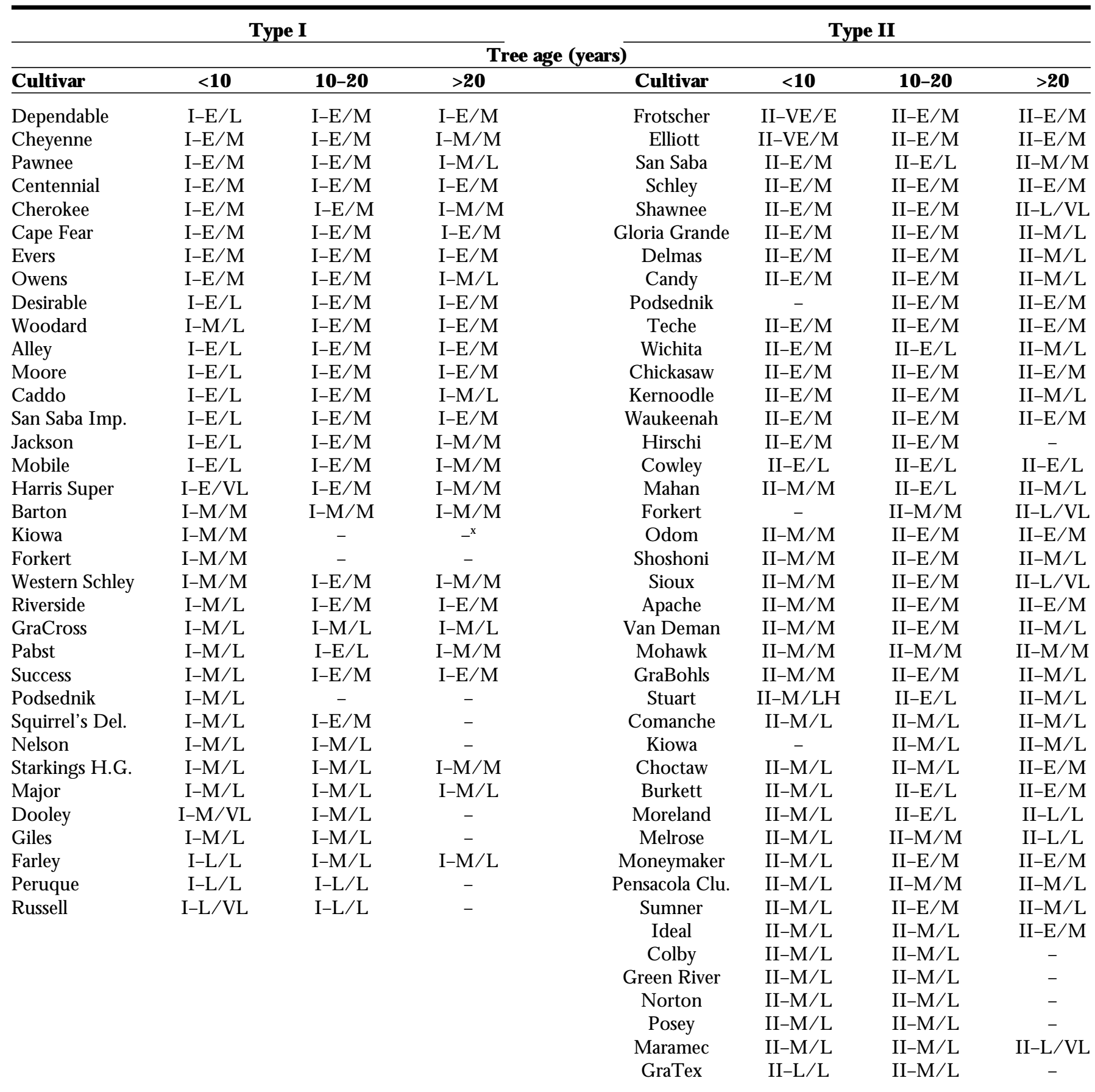

${ }^{2}$ Classification is based on flowering data from Wood et al. (1997) and Worley et al. (1992) for tree growing in Georgia (U .S.). Cultivars may interact with environmental conditions to produce flower classes if grown at locations outside the southeastern U S.

yClassification is as follows: 'D esirable' isclassified as I-E/ L as a young tree (i.e. less than 10 yearsold) and I-E/ M as an old tree (i.e., greater than 20 years old) because of relative changes in flower development with tree age or size. Thus, 'D esirable' is a T ypel, or protaudrous cultivar, as a young tree it typically disperses pollen during the early ( $E$ ) portion of the pollination season and displays receptive flowers during the late $(\mathrm{L})$ phase of the pollination season. Therefore, as I-E/ $\mathrm{L}$, 'D esirable' requires a complementary cultivar, onethat is classified as II-E/ L for pollination (meaning that both cultivars cross-pollinate each other). Thus, as a young tree, only 'T ejas' and 'C owley' are highly complementary with 'D esirable', however, 'D esirable' can be pollinated by any cultivar possessing a II-?/ L classification (where? =VE, E, M , L, VL). This means that 'C urtis', 'C owley', and 'Stuart', etc. are noncomplementary pollinators of young 'D esirable' trees. As a relatively old tree 'D esirable' changes flowering characteristics from I-E/ $L$ to that of $I-E / M$, where the receptivity period shifts from late $(\mathrm{L})$ to mid $(\mathrm{M})$ season. Thus, a mature 'D esirable' tree requires a II-E/ M cultivar in order to be fully complementary (i.e., 'Elliott', 'Gloria Grande', and 'Sumner') whereas II-?/ M and II-E/ ? cultivars would be only partially complementary.

${ }^{\times} D$ ata not available. 
of these chemicals at high rates is unknown.

Boron isanutritional amendment potentially sprayed onto foliage during pollination to enhance fruit-set. It is important in a multitude of physiological processes, including pollen germination and germ tube growth (Tisdale et al., 1993). While plum and apple orchards [Prunus domestica $L$. and Malussylvestris(L.) M ill. domestica (Borkh.) $\mathrm{M}$ ansf.] sometime receive foliar B sprays to enhance fruit-set, it is presently unknown if fruit-set of pecan can be increased by $B$ applications. U npublished observations by the author indicatethat if supplemental fertilization with $B$ enhances fruit-set for pecan, then it probably only does so when foliar $B$ concentration is less than $20 \mathrm{ppm}$. The effect of $B$ nutrition and sprays to canopies likely merits further investigation.

\section{Revised classification of flowering types}

The abundance of evidence for pollination problems in commercial orchards led to reevaluation of the traditional Type I/ II flowering evaluation system long used by pecan growers and extension specialists to select complementary cultivars. Type I cultivars referred to those maturing pollen first (i.e., protandrous) whereas Type II referred to those maturing the pistillate flower first (i.e., protogynous). Because most orchards have been established with the premise that pollinators were only necessary in locations without orchards within the general vicinity, many orchard exists in which there is poor cross-pollination. Additionally, if pollinators werethought to beneeded, then inclusion of a single cultivar from the opposing flowering type was assumed to be adequate. Yet block-type plantings consisting of both a Type I and a Type II cultivar often exhibit pollination related yield losses. Thus, about 80 of the primary cultivars received intensive study regarding staminate and pistillateflower maturity characteristicsover fiveyearsto study flowering phenograms (Worleyet al., 1992; Wood etal., 1997).

The resulting flowering phenogramsrevealed great variability in degree of dichogamy and length of maturity windows within each dichogamy class. Thus, clearly indicating that Type I and Type II cultivars were often non complementary between classes. These results indicated that the traditional Type I/ II system is a relatively crude, low resolution, means of identifying cultivars that ensure crosspollination. The resulting high resolution phenograms showed that pollination and receptivity windows throughout the flowering season could be logically divided into very early, early, mid, late, and very late season protandrous (Type I) and protogynous (Type II) types. Thus, allowing for the development of a relatively high 30-class Type I and Type II alternative to the standard two-classT ypel / II system for selecting cultivars to ensure cross-pollination of yard and orchard trees (Table 1). The potential importance of this enhanced system becomes increasingly apparent when temperature and age/ size related shifts in flower maturity windows are considered. The duration of pollinating and receptivity windows and time interval between these windows shorten as trees age (Wood, 1997). Thus, crosspollination problems are most likely to occur in relatively young orchards (Wood, 1997). Because environmental conditions influence flower maturity, characteristics and flowering classification may vary depending upon location of cultivation.

A nother factor influencing selection of complementary cultivars is the apparent importance of pollen reaching the surface of the stigmatic surface soon after becoming receptive. For 'Cheyenne', maximum fruit set occurred when pistillate flowers received pollen lessthan about $1 \mathrm{~d}$ after becoming receptive, whereas no fruit set occurred when they were pollinated greater than about $4^{+} d$ after initial receptivity (Wood, 1997). Thus, the longer receptive pistillate flowers go without pollination, the less chance for fruit set. This may be especially important in environments wherestigmas are exposed to strong dry winds such as in arid environments. $O$ rchards in Egypt exposed to strong dry winds during pollination season often display poor fruit set attributed to desiccation of the stigmatic surface of pistillate flowers whereas those protected by wind breaks exhibit normal fruit set (personal observation).

\section{Conclusions}

Pollination related problems in commercial U.S. pecan orchards are not only common but can also be severe, even in orchards near large numbers of wild trees. L osses occur as a result of abortion of non fertilized flowers, or due to diminished fruit quality due to self-pollination. This is most likely to occur in block-typeplantings composed of only one or two cultivars. Problems can be identified by pronounced non insect related post pollination fruit drop, decreasing frequency of fruit set with increasing distance from the pollinator row or from off-type genotypes.

Any one of a diverse variety of factors can contribute to cross-pollination problems, but the most likely appearsto befailureto includecomplementary pollinizers in orchards at an appropriate row frequency from the main crop cultivar. A second factor is selection of pollinators based on the relatively low resolution 2-class Type I/ II system traditionally used for selecting complementary cultivars. U se of the relatively high resolution 30class flower maturity classification system to identify pollinators should reduce pollination related losses. L osses can also be reduced by structuring orchards such that the main crop cultivar does not occur in blocks more than four rows across while incorporating two or more complementary pollinizers to ensure cross-pollination when weather or age related factors alter flower maturity windows. The presence of off-type genotypes within orchards can potentially play a major rolein ensuring cross-pollination. Such trees should receive serious consideration prior to removal or top-working. Orchards growing in regions where pistillate flowers are exposed to hot, dry winds during the time of stigma receptivity may benefit from the presence of a windrow on the windward side of the orchard so as to reduce potential losses due to drying of the stigmatic surface.

\section{Literature cited}

Adriance, G.W. 1930. Dichogamy in the pecan. Proc. Amer. Soc. H ort. Sci. 27:435439.

Adriance, G.W. 1931. Factors influencing fruit setting in the pecan. Bot. G az. 91:144166.

Amling, H .J . and K.A. Amling. 1983. Physiological differentiation of pistillate flowers of pecan and cold requirements for their initiation. J. Am. Soc. H ort. Sci. 108:196198.

Flack, J.R. 1970. The spread and domestication of the pecan in the U nited States. 
PhD diss., U niv. of Wis., M adison.

Fowells, H.A. 1965. Silvics of forest trees of the U nited States, Agr. H dbk. 271. GPO, Wash., D.C.

Grauke, L.J. and T.E. Thompson. 1996. Pecans and hickories, p. 185-239. In: J. J anick and J. M oore (eds.). Fruit breeding. vol. 3. Wiley, N ew York.

$\mathrm{H}$ e, Y. and H.Y. Wetzstein. 1994. Pollen degeneration and retarded leaf development from fungicidal spraysapplied during microspore development and shoot expansion. J. H ort. Sci. 69:975-983.

H eslop-H arrison, Y. and K.R. Shivanna. 1977. The receptive surface of the angiospermstigma. Ann. Bot. 41:1233-1258.

I sbell, C.L. 1928. Growth studies on the pecan. Ala. Agr. Expt. Sta. Bul. 266, 1-63.

M adden, G.D. and E.J. Brown. 1975. $\mathrm{H}$ ere are methods to improve pollination. Pecan Q uarterly 9(4):10-12.

$M$ arquard, R.D. 1988. O utcrossing rates in pecan and the potential for increased yields. J. Amer. Soc. H ort. Sci. 113:84-88.

M arquard, R.D. 1992. Fruit-set of pecan requires a low percentage of live pollen in controlled pollination. HortScience 27:473.

M cGranahan, G.H ., D.G. Voyiatzis, P.B. Catlin, and V.S. Polito. 1994. H igh pollen loads can cause pistillate flower abscission in walnut. J. Amer. Soc. H ort. Sci. 119:505509.

M cKay, J.W. 1947. E mbryology of pecan. J. Agr. Res. 74:263-284.

Polito, V.S., S.A. Weinbaum, and T.T. M uraoka. 1991. Adaptiveresponsesof walnut pollen germination to temperature during pollen development. J. Am. Soc. H ort. Sci. 116:552-554.

Reilly, C.C. and B.W. Wood. 1996. No adverse effect of early season fungicide and zinc sprays on leaf area, fruit-set, and nut quality of pecan. HortScience 31:808810.

Romberg, L.D. 1931. The present status of the pecan pollination problem. Proc. Tex. Pecan Grow. Assoc. 11:57-61.

Romberg, L.D. and C.L. Smith. 1946. Effects of cross-pollination, self-pollination and sib-pollination on the dropping, the volume and the kernel development of pecan nutsand on the vigor of the seedling. Proc. Amer. Soc. H ort. Sci. 47:130-133.

Romberg, L.D. and C.L. Smith. 1950. Progress report on the breeding of new pecan varieties. Proc. Texas Pecan Growers Assoc. 29:12-21.

Smith, D. L. and L. D. Romberg. 1932. Pollination control, period of receptivity and pollen viability in the pecan. Proc. Tex. Pecan Grow. Assoc. 12:23-34.

Smith, C.L. and L.D. Romberg. 1940. Stigma receptivity and pollen shedding in some pecan varieties. J. Agr. Res. 60:551564.

Smith, C.L. and L.D. Romberg. 1941. Pollen adherence as a criterion of the beginning of stigma receptivity in the pecan. Proc. T exas Pecan Growers A ssoc. 21:3845.

Sparks, D . and G.D. M adden. 1985. Pistillate flower and fruit abortion in pecan as a function of cultivar, time, and pollination. J. Amer. Soc. H ort. Sci. 110:219-223.

Stuckey, H.P. 1916. The two groups of varieties of the $\mathrm{H}$ icoria pecan and their relation to self-sterility. Ga. Agr. Expt. Sta. Bul. 124

Thompson, T.E. and L.J. Grauke. 1991. Pecans and other hickories (Carya), $\mathrm{p}$. 839-904. In: J.N. Moore and J.R. Ballingtons (eds.). Genetic resources of temperate fruit and nut crops. Intl. Soc. H ort. Sci. 118:415-418.

Thompson, T.E. and R.L. Romberg. 1985. Inheritance of heterodichogamy in pecan. J. Hered. 76:456-458.

Tisdale, S.L., W.L. Nelson, J.D. Beaton, and J. L. H avlin. 1993. Soil fertility and fertilizers. 5th ed. M acmillan, $\mathrm{N}$ ew York, N.Y.

Wetzstein, H.Y. and D. Sparks. 1983. The morphology of pistillateflower differentiation in pecan. J. Amer. Soc. H ort. Sci. 108:997-1003.

Wetzstein, H .Y. and D. Sparks. 1984. The morphology of staminate flower differentiation in pecan. J. Amer. Soc. H ort. Sci. 109:245-252.

Wetzstein, H .Y. and D. Sparks. 1985. Structure and in vitro germination of the pollen of pecan. J. Amer. Soc. H ort. Sci. 110:778781
Wetzstein, H .Y. and D. Sparks. 1986. Flowering in pecan. H ort. Rev. 8:217-255.

Wetzstein, H. Y. and D. Sparks. 1989. Stigma-pollen interactions in pecan. J. Amer. Soc. H ort. Sci. 114:355-359.

Wood, B.W. 1997. Source of pollen, distance from pollinizer, and time of pollination affect yields in block-type pecan orchards. H ortScience 32:1182-1185.

Wood, B. W., J. A. Payne, and L. J . Grauke. 1990. The rise of the U .S. pecan industry. $\mathrm{H}$ ortScience 25:594,721-723.

Wood, B. W. and R. D. M arquard. 1992. Estimates of self-pollination in pecan orchards in the southeastern U nited States. $\mathrm{H}$ ortScience 27:406-408.

Wood, B.W., M.W. Smith, R.E. Worley, P.C. Anderson, T.E. Thompson and L.J. Grauke. 1997. Reproductive and vegetative characteristics of pecan cultivars. H ortScience 32:1028-1033.

Woodroof, J.G. 1924. The development of pecan buds and quantitative production of pollen. Georgia Agr. Expt. Stn. Bul. 144:134-161.

Woodroof, J.G. 1928. Development of the embryo sac and young embryo of $\mathrm{H}$ icoria pecan. Amer. J. Bot. 15:416-421.

Woodroof, J.G. 1930. Studies of the staminate inflorescence and pollen of $\mathrm{H}$ icoria pecan. J. Agr. Res. 40:1059-1104.

Woodroof,J.G. and N.C. Woodroof. 1926. Fruit bud differentiation and subsequent development of the flowers in $\mathrm{H}$ icoria pecan. J. Agric. Res. 33:677-685.

Woodroof,J.G. and N.C. Woodroof. 1927. $\mathrm{D}$ istance pecan pollen is carried by wind for practical purposes. Georgia-Florida Pecan G rowers Association 21:43-45.

Woodroof,J.G. and N.C. Woodroof. 1929. Flowering and fruiting habit of the pecan. Proc. N atl. Pecan Assoc. 28:128-136.

Worley, R.E., S.K. D ove, B.G. M ullinix, J., and M. Smith. 1992. Long-term dichogamy of 80 pecan cultivars. Scientia H ort. 49:93-101.

Yates, I.E. and D. Sparks. 1993. Environmental regulation of anther dehiscence and pollen germination in pecan. J. A mer. Soc. H ort. Sci. 118:699-706. 